\title{
FLT1 wt Allele
}

National Cancer Institute

\section{Source}

National Cancer Institute. FLT1 wt Allele. NCI Thesaurus. Code C52169.

Human FLT 1 wild-type allele is located within $13 q 12$ and is approximately $193 \mathrm{~kb}$ in length.

This allele, which encodes vascular endothelial growth factor receptor 1 protein, is

involved in the control of cell proliferation and differentiation. 